\title{
Література:
}

1. Андреева И.Н. Эмоциональный интеллект: исследования феномена. Вопросы психологии. 2006. № 3. С. 78-86.

2. Mayer J. D., Salovey P. The Intelligence of emotional intelligence. Intelligence. 1993. V. 17. № 4. P. 433-442.

3. Гоулман Д. Эмоциональный интеллект. Почему он может значить больше, чем IQ. Москва: «Манн, Иванов и Фербер», 2013. С. 560.

4. Носенко Е. Л. Емоційний інтелект як форма прояву важливої складової особистісного потенціалу - рефлексивної свідомості. Вісник Дніпропетровського університету. Сер. : Педагогіка і психологія. 2012. Т. 20., Вип. 18. С. 116-122.

DOI https://doi.org/10.30525/978-9934-588-80-8-1.30

\section{PSYCHOLOGICAL CHARACTERISTICS OF MEDICAL STUDENTS FROM THE STANDPOINT OF PREDICTING SUICIDAL BEHAVIOR}

\author{
Tsvirenko S. M. \\ Candidate of Medical Sciences, Associate Professor, \\ Chief of the Department of Pediatrics № 1 \\ with propaedeutics and neonatology \\ Ukrainian Medical Stomatological Academy \\ Pokhylko V. I. \\ Doctor of Medical Sciences, Professor, \\ Professor at the Department of Pediatrics № 1 \\ with propaedeutics and neonatology \\ Ukrainian Medical Stomatological Academy \\ Cherniavska Yu. I. \\ Candidate of Medical Sciences, \\ Assistant at the Department of Pediatrics № 1 \\ with propaedeutics and neonatology \\ Ukrainian Medical Stomatological Academy \\ Poltava, Ukraine
}

Our present is a time of significant information load (often negative), which forces a person to be in a state of prolonged emotional stress. Under such conditions, the frequency of maladaptation states with feelings of 116 
insecurity, insecurity, loss of meaning in life increases, which are expressed in neuropsychiatric and psychosomatic disorders, autoaggressive behavior, and its extreme form - suicide. According to the World Health Organization, suicide is one of the three leading causes of death between the ages of 15 and 35 [3].

Unfortunately, statistics indicate that suicide is «getting younger» over the years, which requires research on this issue and the development of preventive measures among young people. Recently, researchers of autoaggression point to the need to develop and implement effective preventive measures not only for suicidal behavior, but also suicidal tendencies as an active (internal) form of autoaggressive behavior, including both suicidal intentions and involuntary acts that immediately precede their lives.

The aim of our work was to study the psychological condidtion of students of the Ukrainian Medical Stomatological Academy (Poltava) with a possible definition of a group of people with elements of suicidal behavior. We used the «Suicide Risk Questionnaire» (modified by TM Razuvaeva). This questionnaire is most widely used by psychologists in individual and group testing for rapid diagnosis of suicide risk; identifying the level of formation of suicidal intentions in order to prevent serious suicide actions and prevent suicide attempts [1].

The sample of our study consisted of 480 students, among whom were 178 (37\%) students of the Faculty of Medicine № 1, 110 (23\%) - students of the Stomatological Faculty, 108 (22\%) - Foreign Students Faculty, 54 (11\%) future pediatricians, $30(6 \%)$ - medical college students. According to the results of the analysis of the respondents' answers, we found the following features in students: demonstrativeness $-2 \%$; affectivity $-2 \%$; uniqueness $2 \%$; insolvency $-2 \%$ social pessimism $-1 \%$; breaking cultural barriers $3 \%$; maximalism $-7 \%$; time perspective $-1 \%$, anti-suicidal factor $-100 \%$.

Our attention was drawn to the fact that all respondents have an antisuicidal factor, which, even in the presence of all other factors, removes the global risk of suicide. It is a deep understanding of a sense of responsibility for loved ones, a sense of duty. This is the idea of the sinfulness of suicide, its anti-aesthetics, fear of pain and physical suffering. In some sense, this is an indicator of a healthy psychological climate in the student environment.

We interpreted the relatively widespread youthful maximalism among students as a stage of personality formation [2].

Thus, our study showed that a higher educational institution should create for a young person, a future specialist all the necessary conditions for his spiritual development, free worldview and a high level of culture of personal self-affirmation, which will contribute to mental health. 


\section{References:}

1. Kokun O.M., Agayev N.A., Pishko I.O., Lozinskaya N.S., Kornya L.V. Psychological assessment of suicide risk in servicemen. Methodical manual. Kyiv, 2019. 206 p.

2. Sergeenkova OP. Age psychology Kyiv: Center for Educational Literature, 2012. $376 \mathrm{p}$.

3. World Health Organization: http://www.who.int/countries/ukr/en/

DOI https://doi.org/10.30525/978-9934-588-80-8-1.31

\section{READYNESS OF FUTURE SPECIALISTS FOR SELF-EDUCATION ACTIVITY}

\section{Chernihivska N. S.}

Candidate of Pedagogic Sciences, Associate Professor, Head of the Department of Romance and Germanic Languages

National Academy of the Security Service of Ukraine

\section{Ivasyshyna T. A.}

Candidate of Philological Sciences, Associate Professor, Head of the Department of Eastern and European Languages

National Academy of the Security Service of Ukraine

\section{Vinnytska T. M.}

Senior teacher at the Department of Romance and Germanic Languages National Academy of the Security Service of Ukraine

$$
\text { Kyiv, Ukraine }
$$

The aim of the work is to demonstrate the need to form the future professionals' readiness for self-education activities, to form the desire of life-long learning, to emphasis the importance of teachers' psychological and pedagogical skills while formation the conative component of readiness for self-education.

The processes of modernization the higher education in Ukraine have necessitated the development of a new generation of professionals ready for life-long learning. The normative legal documents (Laws of Ukraine «On Higher Education», «On Innovative Activity») clearly outlined the tendencies of educational processes development, which required future specialists to be able to accomplish knowledge throughout life-long learning, what meant to be ready for motivated self-education activity. 